\title{
CALML4 wt Allele
}

National Cancer Institute

\section{Source}

National Cancer Institute. CALML4 wt Allele. NCI Thesaurus. Code C54376.

Human CALML4 wild-type allele is located in the vicinity of $15 q 23$ and is approximately 15

$\mathrm{kb}$ in length. This allele, which encodes calmodulin-like protein 4, may be involved in the modulation of calcium localization. 